\title{
Voicing The Other : Patrick Sweeting's Perspective in Jaipong Dancer
}

\author{
Epata Puji Astuti \\ evelove602@gmail.com \\ Department of English Letters, Universitas Sanata Dharma
}

\begin{abstract}
Jaipong Dancer is a novel written by Patrick Sweeting, which raises the subordination issue of women as the other. In this novel, Sweeting represents women as the other in paradox. On the one hand, women are represented as the other who is excluded from the society. On the other hand, women are represented as (the ones who are) strong, exotic and difficult to be overpowered. The problem is how Patrick Sweeting voices women as the other in his novel and the research questions are (1) how women as the other are voiced in this novel, and (2) how the writer's perspective is related to the problem of women as the other in the novel. To understand the voicing of women as the other by the writer, the researcher uses postcolonial feminism by Gayatri Spivak, especially the concept of white men saving brown women from brown men. Textual analysis method is used to find out the relations and the form of the writer's voice in the novel.

Based on the whole analysis, it can be concluded that women as the other are voiced by the writer as the ones who are strong, exotic and difficult to be overpowered. Through his work, the writer who is assumed doing civilizing mission by voicing the issues related to the subordination of women in the Third World is, in fact, silencing the voice of the Third World women and imprisoned it under the stereotype and prejudice. The perspective which is used by the writer to represent the East is the same as other Orientalists' perspectives. The voice of women in the Third World as depicted in the novel is created by the Western.
\end{abstract}

Key words: voicing, women, the other

\section{Introduction}

Jaipong Dancer is the first novel written by Patrick Sweeting, an English man who lives for several years in Indonesia. This novel raises the issue of a local woman whose proffession is a dancer and her subordination problems. A white man writer talks about a brown woman, and it would be an interesting topic to discuss how the writer represents the East. In the Orientalism, the West objectification has a hierarchical power relation, where the West (the Self) dominates the knowledge about the East (the Other), and their authority represents the East based on Western perspective which is full of power interest from the colonizer to the colonized. The West authority in representing the East creates categorization, stereotype, and representation of prejudice. This argument is refused by Sweeting. Sweeting refuses the prejudice and stereotype, but is this statement reflected in his novel or are there certain interests behind his statement which is generally understood as supporting the East. Orientalists represent the East (woman) as the one who is weak stupid, uncivilized, strange, different, and irrational. They need the West (men) who are strong, rational, and normal to release them from their weakness and stupidity. 
The novel was written in 1950s and took the scene at a migrant village in South Sumatra. It tells about a Javanese classic dancer whose name is Yahyu who has an extraordinary beauty and enchantment in her village. She is an ideal woman, who is called "the exotic" by the West. All the people who see her will appreciate her perfectness. Sweeting represents Yahyu as a Third World woman who is not fully marginalized. As a Javanese classic dancer, Yahyu is categorized as a dominant woman since she has public access, and class, and is not underestimated like the other Third World Women. In this novel Sweeting represents Yahyu as a Javanese classic dancer - who in the end of the story- becomes a Jaipong Dancer. It is interesting to analyze the reason of this change since Javanese classic dance has higher hierarchy than Jaipong dance.

In his novel, Sweeting represents Third World woman paradoxically. On the one hand, Yahyu is represented as the other, insulted woman and excluded from her society because of her unwanted pregnancy. On the other hand, Sweeting represents "the exotic" side of Yahyu. Yahyu who escapes from her house dresses like a beggar with a dirty body, face and hair, but her acts, gestures, and the way of speaking show that she is not an ordinary woman. Everyone who meets her can feel that she is a classy, strong and exotic woman. Her appearance which is like a beggar cannot hide her exoticness. Yahyu as the other, makes not only men, but also all the people fall in love with her.

Sweeting's perspective about the Third World women can be seen from the relations between Yahyu and the white men in his novel. The white men are represented as the one who are powerful and have a big influence on Yahyu's life. The brown men are represented with the physical weakness. Jim Robinson, one of white men in the novel, has a role as "White men are saving brown women from the brown men". Jim rescues Yahyu by marrying her and accepting the baby inside her womb. What Jim does is similar to the abolition of Sati rite by British colonial in India. The West imagines the modernity as benevolent projects to rescue the Third World women from their (primitive) society.
The white men feel having responsibility to rescue and speak for the marginalized women. The "responsibility" feeling becomes a unique problem which is then manifested in real actions, but behind it lies another agenda, which is often aimed to assist their own interest. What about Sweeting's perspective in "Jaipong Dancer" which tries to speak and is generally understood as a support for the Third World women and their rights? Are there any certain agendas or interests behind it? Does he actually justify the West domination?

\section{White Men Saving Brown Women from Brown Men: Voicing or Silencing}

The colonial presence creates the discourse which discriminate the colonized as the weak, irrational, primitive and mystic. On the other hand, the West views the East as something exotic, interesting and sexy. The West studies the East with certain interests. The Western's writing about the East contains hidden values. Then, the discourse which is developed by the West about the East put both of them in binary opposition where one of them surpasses the other. The discourses about the East as the "other" world actually cannot be separated from the interest, authority interest, or ideology interest.

Gayatri Chakravorty Spivak brings the influential idea in her essay Can The Subaltern Speak. Spivak makes the women the essential variable in her theory. For Spivak, colonialism track in the past does not disappear although the independence is officially given but the main life created by the colonial still exists. Spivak questions about how the world is represented from the dominant perspective and at the same time is claimed as an action of voicing practice for the Third World marginalized people. Stephen Morton in his book justifies Spivak's position as postcolonial critic who is present for silenced voices as the main focus. Those silenced voices are the immigrant working class women with all postcolonial subjects and how the colonial history in the past brings the influence to their life nowadays. 
In Can The Subaltern Speak, Spivak presents some social phenomena about silencing women voices in India. Spivak discusses Sati, a tradition of widow burning as the symbol of love and submission of a wife to her husband. When a husband dies, the wife is suggested to follow her husband by burning herself in the husband's funeral pyre. Sati is a form of woman subjection tied to religious tradition which gives a suicide "choice" as her own will. Sati is legitimated as a special sign, a standard of religious value for a woman as a good wife. In 1892 British colonial prohibited Sati since it breaks the law and is against humanism. At this point, the British colonial rescues the women from brown men oppressor, white men are saving the brown women from brown men. In his book, Stephen Morton writes: "By representing Sati as barbaric practice, the Bristish were thus able to justify imperialism as a civilizing mission in which [...] they were rescuing Indian women from the reprehensible practices of a traditional Hindu patriarchal society (Morton, 2003, p. 63).

In Edward Thompson's book with the title Sutee, Spivak sees another problem behind British colonial presence with his civilizing mission: The problem with this book is, indeed, a problem of representation, the construction of a continuous and homogenous 'India' in terms of heads of state and British administrators, from the perspective of 'a man of good sense' who would be the transparent voice of reasonable humanity. 'India' can be represented, in the other sense, by its imperial masters" (Spivak, 1988, p. 101) It is valued as silencing native's voices who are not able to speak up and define their history of civilization. However, the prohibition of Sati by British colonial does not represent white men are saving brown women from brown men, but takes the "freedom choice" of women. Mayo suggests that the sati widow believes she will have an equally suspicious end: 'she escapes a present hell and may hope for happier birth in her next incarnation' (Mayo, 2000, p. 131). Mayo emphasizes that through Sati, the widows believe that it will avoid them from hell and hope for the happier life in the incarnation. It shows that the widow's voice still becomes the representation created by Western perspective.

Gayatri Spivak warns the postcolonial intellectuals about the danger of their claim for the voices of the oppressed. According to her, an intellectual is not able to claim and romanticize their intellectuality to get the attention from the groups for a pragmatic purpose. That intellectual's actions for Spivak are colonial. According to her, that action hegemonizes the various kinds of oppressed groups. If the intellectual group (researcher, cultural observer, academician, etc.) wants to get involved into the oppressed group, what they can do is to report the reality of subaltern and subalternity which is not represented in social space (Spivak, 1988, p. 287). According to Spivak, the duty to narrate, report and interpret the problem of oppressed group cannot be separated from the interpreter subjection from certain point of view since the intellectual's language cannot represent the oppressed group.

Melani-by citing Jaggar's statement (1998)-explains that the intellectual role to show the bad condition of subaltern's group is still important by criticizing their position and terms used to speak about subaltern. The correction of the subject's position is necessary so that the representation of subaltern does not end in silencing (Budianta, 2005, p. 101).

\section{Positioning and Voicing The Other}

In relation to women, Sweeting presents the other as the one who is capable to show her superiority. Although she has a position of an outsider, joining a prostitute group, and experiencing the degradation from a Classic dancer into a Jaipong dancer with negative stereotypes, Sweeting presents the other as the one accepted by the society, getting the sympathy, even becoming the new idol in womanhood.

The ability of the other to be accepted by the society becomes Sweeting's way of voicing in the novel. The presence of Yahyu is well welcomed and accepted. Many women even adore her beauty. Her beauty, elegance and 
soft voice show that Yahyu is not an ordinary woman. In addition, her ability to dance Classic dance makes other women adore her.

In her relation with men, Sweeting presents the other as the one who is able to defeat the domination of men by her exotic value. The exoticism which defeats the dominant men is a form of Sweeting's voicing in his novel. Sweeting also voices the other by presenting Jim, a white man who becomes Yahyu helper (white men are saving brown women). The presence of Jim is like a goldfield for Yahyu. Jim, a white man and the owner of tea plantation, wants to accept the baby in her womb.

Public marriage is Yahyu's will to voice that she is not an excluded woman anymore. It will send Yahyu to her previous position, also make her get the honor in her village. Jim becomes the access for Yahyu to raise her children in a good condition.

Yahyu voices herself by wounding her beautiful face. She does not want to be beautiful anymore. Beauty just brings her suffering. The wound on her face makes Yahyu have a choice to say "No" to men.

The author voices Yahyu by killing Hans. By killing Hans, Yahyu voices her will to be free from Hans, a white man who makes her suffer and lose her beloved. After killing Hans, Yahyu tries to kill herself, but there is no bullet left. She does this action as the voice for her bad fate.

In the end, Yahyu goes back to dance again but she joins a Jaipong dancer group. The author voices Yahyu's representation as being degraded, but she still tries to be independent and gets the money for herself.

\section{Writer's Position and Perspective}

\section{The Representation of Women as other}

The stereotypes built by the West about Eastern women are about the discourse of "the scary but seductive dragon ladies of China, the demure geisha of Japan, and the sexy belly dancers and mysteriously veiled women form the Arab world. The Third World women's stereotypes can be divided into two groups: "China Doll" and "Dragon Lady". China Doll or "Geisha Girls" is the representation of Third World women who are shy, passive and exotic, and "Dragon Lady" is used to show the aggressive, strong and unfriendly women, as what Leong said "an overly aggressive and dominant Oriental female".

Sweeting presents Yahyu as the Third World woman who is more extraordinary than the other Third World women. Yahyu lives in a patriarchal society, where women become the second class after men. When other women just dominate the domestic space, Yahyu shows that she is more dominant by having public access. Sweeting's representation is also shown by the profession of Yahyu as a classic dancer in which she usually plays the role of Sita. Sweeting shows that Yahyu is an extraordinary Third World woman because not all dancers can play the role of Sita. The hierarchy of classic dance shows that Yahyu is an Eastern woman with high values, she is appreciated, admired and loved.

In the family, the construction of culture positions women as the second class where their life is only within domestic area (Gandhi, 2006: xvi). It means, women are viewed as a low grade. However, it does not happen in Yahyu's family. Yahyu becomes the symbol of pride for her family, a classical dancer who is admired by all the people in her village. Of course, it increases the values of her family. The representation of Yahyu as Dragon Lady is always presented by Sweeting in his novel.

Yahyu, a strong and powerful Dragon Lady, should be degraded from her high position and becomes the other - the excluded woman. She becomes the other since she experiences her unwanted pregnancy. Yahyu changes into the other who cannot speak. She cannot speak for the Eastern norm that is against extra-marital sex. Yahyu, who finds her hope in Jim, should face the bad fate when she is submitted by Hans, a white man who is obsessed with Yahyu. Yahyu becomes an asset to gain power. The way Sweeting represents Yahyu as Third World woman who is strong, exotic, active and independent, is 
contradictory with the end of her story. In the end, Sweeting represents the Third World women as an object who can be submitted.

\section{Writer's Position: Voicing that Ends with the Silencing}

Sweeting's position can be known from how he responds and voices the subordination issues that happen in the East. Yahyu who is reputed to have broken the morality because of extra-marital sex issues should face the subordination issue, that is polygamy. Sweeting tries voicing her by making her escape to find her uncle in the goldfield. This voicing articulates the desire of the Third World women to be independent. In the end, howeve, Yahyu's voicing ends with silencing because at the end of the novel she never becomes an independent woman. She has been degraded into a Jaipong dancer and has lived in the prostitution house, House of Young Bamboo.

Another subordination issue discussed by Sweeting is the presence of women as the other, excluded from the society. Sweeting tries to speak for the East by presenting the other as the one who is exotic and the presence is accepted by the society. On the contrary, this voicing also ends up with silencing. Although Sweeting presents the other as an exotic woman, she is never a part of the society. She is still excluded. Although Yahyu is welcome, she cannot stay as a villager because she does not obey the norm.

Subordination issue is also discussed by Sweeting is marriage value. Sweeting tries voicing the other by a public marriage planned by Yahyu and Jim. Public marriage is a way to rehabilitate Yahyu's honor. This voicing also end up with silencing because the public marriage planned by Yahyu and Jim was successfully failed by Hans. Yahyu cannot show her voice because of Hans' oppression. Sweeting's voicing by presenting Jim as white man saving brown woman from brown man also end up with silencing after Hans appears as white man who oppresses Yahyu's life. Sweeting who is voicing the other powerfully, in the end he is silencing the voice of the other. This silencing becomes the proof of his position that is supporting the West.

\section{Conclusion}

Women as the other are voiced by the author as strong, hard to defeat and not easily giving up. The author shows "the exotic" powerfully. As the other, the women are able to defeat the white men who have power and authority. The author presents the women as the ones who show the resistance.

Sweeting, through his writing, which is assumed as the one who carries a civilizing mission by voicing the subordination issues in the Third World, in fact silences the voice of the Third World women and put it under stereotypes and prejudice. By his authority as the West, Sweeting represents the East based on Western perspective which is full of power interest from the colonizer to the colonized. His writing, which is assumed to stand for the East because it shows the idea of white men are saving brown women from brown men, is in fact full of imperial values. That imperial value becomes the reason for him to promote feminism as something important and good. It shows that the voice of the Third World women still becomes the representation created by the Western perspective.

\section{References}

Beauvoir, De Simone. (1967). The Second Sex. London : Jonathan Cape.

Budianta, Melani. (2005). "Perempuan, Seni Tradisi, dan Subaltern: Pergulatan di Tengah-tengah Lalu Lintas Global-Lokal" dalam Perempuan Multikultural: Negosiasi dan Representasi, Edi Hayat dan Miftahus Surur (Ed.) (Depok: Desantara, 2005)

Chin, J. (1999). Mongrel: Essays, Diatribes, and Pranks. New York: St. Martin Press. 
Gandhi, Leela. (2006). Teori Poskolonial: Upaya Meruntuhkan Hegemoni Barat. Yogyakarta: Qalam.

Leong, K. J. (2005). The China Mystique: Pearl S. Buck, Anna May Wong, Mayling Soong, and the Transformation of American Orientalism. Berkeley and Los Angeles, California: University of California Press.

Lewis, Reina. (1996). Gendering Orientalism" Race, Femininity and Representation. London: Routledge.

Mayo, Katherine. (2000). Mother India, ed. Mrinalini Sinha. Michigan: The University of Michigan Press.

Morton, Stephen. (2003). Gayatri Chakravorty Spivak. London: Routledge. p. 63

Spivak, Gayatri. (1988). Can The Subaltern Speak dalam Marxism and the Interpretation of Culture, Cary Nelson dan Lawrence Grossberg (Ed.) London: Macmillan Education LTD.

Sweeting, Patrick. (2012). Jaipong Dancer. Singapore : Monsoon Books. 